\title{
The significance of markers in the diagnosis of endometrial cancer
}

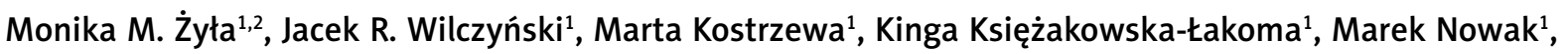 \\ Grzegorz Stachowiak' ${ }^{1}$, Krzysztof Szyłło ${ }^{1}$, Tomasz Stetkiewicz ${ }^{1}$
}

${ }^{1}$ Department of Operative Gynaecology and Gynaecological Oncology, Polish Mother's Memorial Hospital - Research Institute, tódź, Poland ${ }^{2}$ Chair of Midwifery, Gynaecology and Gynaecological Oncology, Medical University of tódź, Poland

\begin{abstract}
Endometrial cancer is one of the most common cancers experienced by women throughout the world. It is also the most common malignancy within the female reproductive system, representing $37.7 \%$ of all disorders. The incidence increases with age, and is diagnosed most frequently in women between 45 and 65 years old. In the last few years, numerous studies have been performed to identify tumour biomarkers. Biomarkers include not only protein routinely used as tumour markers but also genes and chromosomes. The limiting factor in the use of markers in the diagnosis of endometrial cancer is their lack of specificity. However, specific markers for endometrial cancer are the subject of much research attention. Although moderately elevated levels of markers are present in a number of inflammatory or non-malignant diseases, significantly increased levels of markers indicate the development of cancer. Recently, research has been focused on the identification of molecular changes leading to different histological subtypes of endometrial cancer. In this paper the authors reviewed several currently investigated markers. Progress in these investigations is very important in the diagnostics and treatment of endometrial cancer. In particular, the identification of novel mutations and molecular profiles should enhance our ability to personalise adjuvant treatment with genome-guided targeted therapy.
\end{abstract}

Key words: endometrial cancer, diagnostics, markers.

\section{Introduction}

Endometrial cancer is one of the most common cancers experienced by women throughout the world. It is also the most common malignancy within the female reproductive system, representing $37.7 \%$ of all disorders [1]. The incidence increases with age and is diagnosed most frequently in women between 45 and 65 years old $[2,3]$.

The factors that increase the risk of developing endometrial cancer include age, obesity, diabetes, early menarche, late menopause, anovulatory cycles, menstrual disorders, polycystic ovary syndrome, hormone replacement therapy (HRT), childlessness, and oestrogensecreting tumours [4].

Around $80 \%$ of endometrial cancers are adenocarcinomas, $60-65 \%$ of which are endometrioidal cancers $[5,6]$. Other rare kinds of endometrial cancer include serous and clear cell adenocarcinoma, mixed type endometrial cancer, mucinous adenocarcinoma, squamous cell carcinoma, endometrioidal cancer with squamous metaplasia, small cell neuroendocrine carcinoma, and transitional cell carcinoma [5]. The most important clinico-pathological prognostic variables are
FIGO stage, tumour grade, lymph node, and lymphvascular space status, as well as depth of myometrial invasion.

Endometrial cancers are divided into two types. The characteristics of both types are given in Table I.

In the last few years, numerous studies have been performed to identify tumour biomarkers. As defined by the Biomarkers Definitions Working Group, "a biomarker is a biological molecule present in the blood or any other body fluids or in the tissue. This molecule is a sign of normal or abnormal process, good condition or a disease" [7]. Biomarkers include not only proteins routinely used as tumour markers but also genes and chromosomes. The limiting factor in the use of markers in the diagnosis of endometrial cancer is their lack of specificity. However, specific markers for endometrial cancer are the subject of much research attention. Although moderately elevated levels of markers are present in a number of inflammatory or non-malignant diseases, significantly increased levels of markers indicate the development of cancer.

Recently, research has been focused on the identification of molecular changes leading to different histological subtypes of endometrial cancer. 
Tab. I. Characteristics of type I and II endometrial cancer

\begin{tabular}{|c|c|c|}
\hline & Type I endometrial cancer & Type II endometrial cancer \\
\hline Type & Endometrioidal cancer & Non-endometrioidal cancer \\
\hline Development & $\begin{array}{l}\text { Perimenopausal age } \\
\text { Chronic oestrogen stimulation } \\
\text { Anovulatory cycles } \\
\text { Obesity } \\
\text { Hypertension } \\
\text { Diabetes }\end{array}$ & $\begin{array}{l}\text { Age over } 65 \text { years } \\
\text { No oestrogen stimulation } \\
\text { Atrophic endometrium }\end{array}$ \\
\hline Incidence & $80 \%$ of endometrial cancers & $20 \%$ of endometrial cancers \\
\hline The initial change & $\begin{array}{l}\text { Endometrial intraepithelial neoplasia (EIN) } \\
\text { Atopic hyperplasia }\end{array}$ & Endometrial intraepithelial carcinoma (EIC) \\
\hline Method of spreading & $\begin{array}{l}\text { Infiltration of the myometrium } \\
\text { Spreading through the lymphatic vessels }\end{array}$ & $\begin{array}{l}\text { Deep infiltration of the myometrium } \\
\text { Spreading through the lymphatic vessels }\end{array}$ \\
\hline Course of the disease & $\begin{array}{l}\text { Slow and stable } \\
\text { High five-year survival rate (80-85\%) }\end{array}$ & $\begin{array}{l}\text { Aggressive } \\
\text { Peritoneal and lymph nodes metastases } \\
\text { Five-year survival rate is low }(30-70 \%)\end{array}$ \\
\hline Grade & Low grade and good prognosis & High grade and poor prognosis \\
\hline Receptors & $\begin{array}{l}\mathrm{ER}+ \\
\mathrm{PR}+\end{array}$ & $\begin{array}{l}\text { ER- } \\
\text { PR- }\end{array}$ \\
\hline Molecular disorders & $\begin{array}{l}\text { DNA repair genes } \\
\text { PTEN (40-80\%) } \\
\text { K-ras (20-35\%) } \\
\text { microsatellite instability (20-40\%) } \\
\text { PIK3CA } \\
\beta \text {-catenin }(30-40 \%) \\
\text { TP53 }(5-10 \%) \\
\text { E-catherin }(10-15 \%) \\
\text { p16 (10\%) }\end{array}$ & $\begin{array}{l}\text { Microsatellite instability (up to } 5 \% \text { ) } \\
\text { PTEN (10\%) } \\
\text { K-ras (up to 5\%) } \\
\text { TP53 (90\%) } \\
\beta \text {-catenin (up to 5\%) } \\
\text { E-catherin (80-90\%) } \\
\text { p16 (40\%) }\end{array}$ \\
\hline
\end{tabular}

\section{Serum biomarkers}

\section{CA125}

CA125 is routinely tested as part of the diagnosis and treatment of endometrial cancer, and its determination before treatment can be valuable in the staging of endometrial cancer. Increased concentrations of CA125 (> $35 \mathrm{U} / \mathrm{ml}$ ) correlate with clinical stage, depth of tumour invasion, tumour grade, lymph node status, cervical invasion, and peritoneal cytology [8-10].

However, the diagnostic sensitivity of CA125 in endometrial cancer is unsatisfactory, especially in early tumour stages. Also CA125 specificity in endometrial cancer is low: elevated CA125 is commonly known to occur in many non-malignant diseases such as inflammation or endometriosis. Serum concentrations of CA125 are elevated in only $10-20 \%$ of women with early stage of endometrial cancer, and $25 \%$ of asymptomatic patients with recurrences will present with elevated CA125 levels. The use of CA125 for endometrial cancer detection is restricted to advanced-stage diagnosis [11, 12]. However, an elevated preoperative CA125 level is an independent predictor for poor diagnosis $[13,14]$. Saarelainen et al. report that the presence of both HE4 and CA125 together has a higher predictive value than when each is tested individually [15].

\section{CA15.3}

The clinical utility of other known tumour markers such as CA15.3 have proven to be unsatisfactory in patients with endometrial cancer. Serum CA15.3 levels are increased in $24-32 \%$ of patients with endometrial cancer. Scambia et al. found a significant relationship between serum CA15.3 levels (> $30 \mathrm{U} / \mathrm{ml}$ and $>50 \mathrm{U} / \mathrm{ml}$ ) and shorter survival ( $p=0.0004$ and $p=0.00025)$, respectively [16].

\section{HE4}

The human epididymis protein (HE4) is a potential biomarker useful in the diagnosis of ovarian cancer. Elevated levels of HE4 are also observed in patients with endometrial cancer. Moore et al. report that serum HE4 was elevated in all stages of disease, and that serum HE4 levels were more sensitive than serum CA125 in early stage disease [17]. The serum concentration of HE4 has been shown to correlate with the depth of myometrial invasion and the stage of endometrial carcinoma (see Table II and III) [18-20].

Mutz-Dehbalaie et al. found HE4 to be a prognostic value for overall survival, based on univariate $(p=$ $0.001)$ and multivariate $(p=0.023)$ analysis of a group 
Tab. II. Relationship between serum HE4 concentration and depth of myometrial invasion

\begin{tabular}{|c|c|c|c|c|c|}
\hline Author [ref.] & Cases $(N)$ & $\operatorname{EEC}(N)$ & Depth of myometrial invasion & Mean HE4 (pmol/l) & $p$ \\
\hline \multirow{2}{*}{ Bignotti et al. [18] } & \multirow{2}{*}{153} & \multirow{2}{*}{138} & $<50 \%$ & 66.0 & \multirow{2}{*}{$<0.01$} \\
\hline & & & $>50 \%$ & 98.0 & \\
\hline \multirow{2}{*}{ Antonsen et al. [19] } & \multirow{2}{*}{352} & \multirow{2}{*}{335} & $<50 \%$ & 53.7 & \multirow{2}{*}{$<0.0001$} \\
\hline & & & $>50 \%$ & 88.5 & \\
\hline \multirow{2}{*}{ Angioli et al. [20] } & \multirow{2}{*}{204} & \multirow{2}{*}{101} & $<50 \%$ & 63.4 & \multirow{2}{*}{0.012} \\
\hline & & & $>50 \%$ & 108.7 & \\
\hline
\end{tabular}

HE4 - human epididymis protein 4, EEC - endometrioid endometrial carcinoma

Tab. III. Relationship between serum HE4 concentration and FIGO stage

\begin{tabular}{|c|c|c|c|c|c|}
\hline Author [ref.] & Cases $(N)$ & $\operatorname{EEC}(N)$ & FIGO & Mean HE4 (pmol/l) & $p$ \\
\hline \multirow{4}{*}{ Angioli et al. [20] } & \multirow{4}{*}{204} & \multirow{4}{*}{101} & I & 85.8 & \multirow{4}{*}{$<0.05$} \\
\hline & & & II & 147.8 & \\
\hline & & & III & 140.3 & \\
\hline & & & IV & 588.3 & \\
\hline \multirow{9}{*}{ Antonsen et al. [19] } & \multirow{9}{*}{352} & \multirow{9}{*}{335} & AEH & 40.1 & \multirow{9}{*}{$<0.0001$} \\
\hline & & & IA & 54.4 & \\
\hline & & & IB & 78.4 & \\
\hline & & & II & 74.0 & \\
\hline & & & IIIA & 105.5 & \\
\hline & & & IIIB & 211.2 & \\
\hline & & & IIIC & 111.8 & \\
\hline & & & IVA & 702.4 & \\
\hline & & & IVB & 430.1 & \\
\hline \multirow{2}{*}{ Bignotti et al. [18] } & \multirow{2}{*}{153} & \multirow{2}{*}{138} & $I+I \mid$ & 74 & \multirow{2}{*}{$<0.01$} \\
\hline & & & $\mathrm{III}+\mathrm{IV}$ & 112 & \\
\hline
\end{tabular}

HE4 - human epididymis protein 4, EEC - endometrioid endometrial carcinoma

of patients with endometrial cancer. They suggested that preoperative HE4 serum levels are independent prognostic marker in patients with endometrial carcinoma [21]. Saarelainen et al. noted a statistically significant relationship between median concentrations of HE4 and metastases ( $p=0.001$ ), deep myometrial invasion $(p<0.001)$, patient age $(p<0.01)$, body mass index $(p<0.01)$, and histologic grade $(p=0.012)$ [15].

\section{VEGF}

Angiogenesis is an essential process in the development of tumours. The role of angiogenic factors in the development of endometrial cancer has been a persistent subject of study. The most powerful angiogenic factor is known to be vascular endothelial growth factor (VEGF). VEGF plays a crucial role in the initiation of physiological and pathological angiogenesis. Elevated levels of VEGF have been shown in patients with endometrial cancer [22]. Studies have shown a relationship between the blood level of VEGF and the clinical stage of cancer [23].
Overexpression of VEGF and its receptors are related to poor prognosis in patients with endometrial carcinomas [23]. Several anticancer treatments are being studied as possible means of targeting VEGF and its receptors, but the success with these agents has been limited. VEGF and VEGFR1 overexpression was associated with poor prognosis compared to patients with negative tumours $(p<0.001)$. VEGF and VEGFR-1 overexpression may be a useful marker for predicting five-year DFS in patients with endometrioid endometrial cancer [24].

Kamat et al. reported that patients with high VEGF expression had a 19-fold higher risk of death compared to patients with low VEGF expression $(p=0.002)$. They also found a statistically significant relationship between the high risk of death due to disease and the presence of a grade $3(p<0.001)$ or high stage $(p<0.001)$ tumour [25]. These studies confirm the results of other researchers $[26,27]$. Conversely, Fine et al. did not report any significant relationship between the expression of VEGF, flt-1, or KDR/flk-1 receptors and the presence of metastases, rates of recurrence, or patient survival [28]. 
Another factor belonging to the VEGF family is placental growth factor (PLGF), which is a positive regulator of angiogenesis. The role of PLGF has been investigated in several cancer types, including breast or colorectal cancer $[29,30]$. Coenegrachts et al. found that PLGF serum levels were increased only in stage 4 endometrial cancer. In addition, local PLGF protein levels had no effect on disease-free survival or overall survival [31]. Despite this, the role of PLGF in the development of endometrial cancer has not been thoroughly investigated.

\section{Genetic biomarkers}

Different molecular profiles are known to be involved in endometrial carcinogenesis (see Tables I and IV).

\section{DNA ploidy}

Aneuploidy is an abnormal number of chromosomes. It is the most common genetic abnormality observed in cancer cells. Aneuploidy is associated with mutations in tumour suppressor genes and loss of mismatch repair genes. Many investigators report that DNA ploidy is an important prognostic factor in patients with endometrial carcinoma. Aneuploid tumours account for approximately $16-28 \%$ of endometrial cancers. Aneuploidy is correlated with such clinico-pathological variables as histological type of cancer, especially non-endometrioid cancers, old age at diagnosis, lymph node involvement, high tumour grade, and increased risk of disease recurrence [32]. Generally, aneuploid endometrioid endometrial carcinomas have a DNA index (DI) below 1.20, whereas aneuploidy serous adenocarcinomas have a DI greater than 1.60 . Pradhan et al. reported that patients with aneuploid endometrial carcinomas with a DI above 1.20 demonstrate a poorer progression-free survival rate and overall survival rate compared to patients with diploid cancers [33].

Similarly, Susini et al. demonstrated that patients with aneuploidy tumours demonstrate higher recurrence rates of the disease (44.9\%) than patients with diploid tumours $(11.2 \%)(p<0.0001)$. The disease-free interval was also shorter in patients with aneuploid tumours, compared with diploid tumours, the durations being 16 and 37 months, respectively. They also demonstrated a statically significant relationship between DNA ploidy and mortality $(p<0.0001)$. The authors suggest that DNA ploidy and disease stage should be taken into account when planning treatment [34].

\section{Suppressor genes}

\section{PTEN}

PTEN mutations are the most frequent genetic alterations seen in endometrial cancer. The PTEN gene is a tumour suppressor gene located on chromosome $10 q 23$. PTEN inactivation is caused by mutations and leads to loss of expression [35]. PTEN mutations occur in about $55 \%$ of endometrial cancers, particularly in endometrioid endometrial carcinomas and tumours with microsatellite instability (MSI) [36, 37].

PTEN mutations occur in endometrial hyperplasia and in the early stages of endometrial cancer, suggesting that PTEN mutations may be an early diagnostic factor. PTEN is an important regulator of the PI3K-AKT pathway, and it plays a significant role in the maintenance of genomic integrity [38, 39]. McConechy et al. studied the differences in the expression of PTEN in ovarian endometrioid carcinomas and endometrial endometrioid carcinomas. They found that PTEN mutations are more frequent in endometrial endometrioid carcinomas compared to ovarian endometrioid carcinomas $(p<0.0001)$ [40]. Loss of PTEN function is associated with better clinical outcome in patients with advanced or recurrent disease. In patients with early stage of disease, this did not appear to impact on survival [41].

\section{TP53 gene and p53 protein}

The TP53 tumour suppressor gene, located on chromosome 17 , is the most commonly mutated gene in human cancers, and it plays an important role in the biology of gynaecological carcinomas. Its role is to prevent the proliferation of cells with damaged DNA. TP53 arrests the cell cycle by increasing the expression of p21. TP53 mutations are twice as common in serous carcinomas than in endometrioid endometrial carcinomas and occur at an early stage of disease $[36,42]$. p53 protein overexpression is correlated with advanced state of the disease, poor differentiation, deep myometrial invasion, lymph node metastases, and lower survival rates [43-45]. Lia et al. examined the expression of TP53 in normal endometrium ( $0 \%)$, endometrial hyperplasia (43\%), endometrial intraepithelial carcinoma (72\%), and serous endometrial carcinoma (96\%) and found the incidence of TP53 gene mutations to be highest in poorly differentiated tumours ( $43 \%$ in $\mathrm{G} 3,8 \%$ in $\mathrm{G} 2$, and $0 \%$ in G1) [46-48].

Patients with p53 gene mutations and p53 protein overexpression demonstrate a higher mortality rate than patients without p53 alterations $[49,50]$. Saffari et al. found that patients with p53 gene mutations had

Tab. IV. The most common gene mutations present in endometrial cancers

\begin{tabular}{|c|c|c|}
\hline & Suppressor genes & Oncogenes \\
\hline $\begin{array}{l}\text { Endometrioid endometrial } \\
\text { carcinoma }\end{array}$ & PTEN & $\begin{array}{l}\text { K-ras } \\
\text { PI3K }\end{array}$ \\
\hline $\begin{array}{l}\text { Serous endometrial } \\
\text { carcinoma }\end{array}$ & $\begin{array}{l}\text { p53 } \\
\text { p21 } \\
\text { p16 }\end{array}$ & HER2/neu \\
\hline
\end{tabular}


the same survival rates as untreated patients without p53 mutations [51].

\section{p21 and p16}

TP53 increases the expression of the p21/WAF1 gene, whose protein product is an inhibitor of cyclindependent kinases. p16 is a cell cycle regulator. Loss of $15 /$ CDKN2A protein expression occurs in approximately $67 \%$ of endometrial cancers [52]. Researchers have demonstrated high p16 expression in serous endometrial carcinoma. Overexpression of p16 was found in $36 \%$ of endometrioid patients compared to $78 \%$ of serous papillary patients.

However, this high expression has not been shown to have any significance in the context of endometrial cancer. Further studies must be performed [53, 54]. Abu Backer et al. reported p21/WAF1 expression to be significantly associated with infiltration of the corpus and lymph node metastasis for adenocarcinoma of the cervix. P16/INK4a expression is associated with histological grade but not histological type of endometrioid endometrial carcinoma [55].

\section{Oncogenes}

\section{Her2/neu}

HER2/neu (ErbB2) is a member of the human epidermal growth factor receptor (EGFR) family of transmembrane tyrosine kinases consisting of EGFR (HER1, ErbB1), HER2/neu (ErbB2), HER3 (ErbB3), and HER4 (ErbB4) [56]. It is normally inactivated, but its activation causes uncontrolled cell division. HER2/neu overexpression was found in about $10-20 \%$ of endometrioid carcinomas and is a potential factor indicating late progression, differentiation events, and poor survival [57, 58]. Patients with HER2-amplified uterine endometrial carcinoma had shorter overall survival rates than those without. In addition, patients with high HER2 copy numbers had poorer prognoses than patients with low HER2 amplification ratios [59]. Some researchers have reported a correlation between HER2 overexpression/ amplification and tumour grade [58,60].

Overexpression of HER2/neu was detected in approximately $14 \%$ and $80 \%$ of serous endometrial carcinomas, with HER2 amplification ranging from $21 \%$ to $47 \%$ [61-65]. Satin et al. reported the highest frequency of Her2/neu overexpression in uterine serous papillary cancer to be approximately $80 \%$, whereas Togami et al. reported the lowest level of HER2 overexpression: approximately $14 \%[66,67]$.

The wide range of HER2 overexpression can be explained by the small sample size used in individual studies, differences in clinical and histopathological factors, entry mixed histologic tumours, and differences in research methods. Several publications suggest that HER2 may be a promising therapeutic target.

Trastuzumab (Herceptin, Genentech, San Francisco, California) is a human monoclonal antibody approved by the Food and Drug Administration (FDA) for the treatment of HER2/neu-overexpressing breast cancer and metastatic gastric cancer. Although some studies have reported that trastuzumab shows activity in patients with advanced or recurrent endometrial cancer, the results of study GOG-181B, a Phase II trial of single agent trastuzumab in patients with advanced or recurrent endometrial cancer, reveal no significant clinical activity of the drug $[62,68,69]$.

\section{PI3K=AKT=mTOR}

The PIK3-PTEN-AKT signalling pathway is the most commonly altered pathway in endometrial carcinoma. It regulates multiple processes such as proliferation, apoptosis, cell growth, or angiogenesis. In normal cells, the PTEN gene product, a lipid phosphatase, inhibits the activity of the PI3K-AKT-mTOR pathway. The lack of PTEN function leads to excessive activation of this pathway $[70,71]$. Alterations in these pathways are commonly observed in endometrioid endometrial cancer: they have been noted in about $80 \%$ of cases [72]. In endometrial cancer, the most common mutations are for the PIK3CA gene, which in $24-36 \%$ of cases coexist with PTEN mutations and are associated with poor prognosis. Oda et al. indicate that PIK3CA mutations are more common in tumours with PTEN mutations, but did not show poorer survival rates compared with patients without PIK3CA mutations. Mutations in the PIK3CA exon 20 are most common in high-grade tumours while mutations in exon 9 occur in low-grade carcinomas. Patients with PIK3CA and $\mathrm{p} 53$ alterations had shorter survival compared with patients with only p53 mutations $(p=0.0001)[73,74]$. No et al. report that overexpression of mTOR occurred in $7.1 \%$ of endometrial carcinomas. mTOR overexpression showed a positive correlation with patient age, menopausal status, and COX-2 expression $(p<0.05)$, but it was not associated with depth of myometrial invasion, tumour grade, stage and histological type, lymph node status, and survival [75].

\section{FGFR2}

Fibroblast growth factor receptor (FGFR2) is a tyrosine kinase that regulates cell angiogenesis and metastasis. Mutations of FGFR2 have been found in about $12 \%$ cases of endometrial cancer [76]. Byron et al. report the presence of FGFR2 mutations in $10 \%$ of tested primary uterine samples. They note that FGFR2 mutations coexist with PTEN loss of function mutations, but FGFR2 and $\mathrm{K}$-ras mutations were mutually exclusive. Endometrial 
cancer cells with FGFR2 mutations are more sensitive to killing by PD173074, a pan-FGFR inhibitor. These findings suggest that mutant FGFR2 is a potential therapeutic target $[77,78]$.

\section{K-ros}

Mutational activation of K-ras oncogene is another genetic change involved in endometrial carcinogenesis. K-ras mutations are present in $10-30 \%$ of sporadic endometrial cancers, especially in endometrioid endometrial cancers, as well as in atypical endometrial hyperplasia. K-ras mutations coexist with MSI [79-81]; however, they are very rare in serous and clear cell carcinomas. Although the relationship of Tamoxifen with K-ras mutations in endometrial cancer is inconclusive, some authors have reported a close relationship between them. Hachisuga et al. reported a significantly higher frequency of K-ras mutations in endometrial polyps in patients treated with tamoxifen (64\%), and Wallen et al. reported increased occurrence of K-ras mutations in normal endometrial tissue in patients treated with tamoxifen [82, 83]. K-ras mutations have been associated with patient age, tumour stage, deeper myometrial invasion, lymph node metastases, and poor survival $[84,85]$.

\section{MSI}

Microsatellite instability (MSI) is the condition of genetic hypermutability that results from impaired DNA Mismatch Repair (MMR). DNA MMR corrects errors that spontaneously occur during DNA replication, like single base mismatches or deletions and short insertions. Cells with an abnormally functioning MMR system, indicated by the presence of MSI, tend to accumulate errors. Microsatellite instability may result in colon cancer, gastric cancer, endometrial cancer, ovarian cancer, hepatobiliary tract cancer, urinary tract cancer, brain cancer, and skin cancers [86]. This association between MSI and malignancy was first recognised in patients with hereditary nonpolyposis colorectal cancer (HNPCC), in which germline mutations occur in the genes of the MMR system.

While MSI in $15 \%$ of sporadic colorectal and endometrial cancers result from the hypermethylation of the $M L H 1$ gene promoter, MSI tumours in Lynch syndrome are caused by germline mutations in MLH1, MSH2, MSH6, and PMS2 $[87,88] . M L H 1$ is a mismatch repair gene responsible for preserving genomic stability, and loss of MLH1 function leads to an accumulation of mutations, which leads to carcinogenesis [89]. Colorectal tumours with MSI are associated with poor differentiated tissue, high mucinogen content, as well as the presence of tumour infiltrating lymphocytes and a Crohn's-like host response [87].
Microsatellite instability occurs in $75 \%$ of endometrial cancers associated with HNPCC. Women with HNPCC have a 10 -fold greater risk of endometrial cancer compared with women from the general population [90]. Microsatellite instability overexpression has been found to be higher in endometrial cancer tissue compared with controls ( $40 \%$ vs. $12 \%, p<0.05)$.

However, the role of MSI in predicting the clinical course of endometrial cancer is unclear. Mackay et al. report that MSI occurs in the early stages of the disease, and it has been associated with a worse prognosis [41, 91]. An et al. note that MSI is much more common in endometrioid endometrial carcinoma than serous endometrial carcinoma ( $20 \%$ vs. $0 \%, p<0.001)$. They also demonstrate a statistically significant relationship between the incidence of MSI and histologic grade, lymph vascular metastases, higher clinical stage, deep myometrial invasion, and unfavourable course of disease [92]. Conversely, Black et al. and Maxwell et al. report that MSI is associated with good prognosis [93, 94]. However, other authors have not shown any significant association between MSI and clinical course [95, 96]. Steinbakk et al. report that MSI positivity is an indicator of an unfavourable course of endometrial cancer in FIGO 1, but not in FIGO 2-4 [97].

\section{ER and PR}

Oestrogen receptor (ER) and progesterone receptor (PR) expression has been observed in $60-70 \%$ of endometrial cancers. The expression of these receptors correlates with tumour stage and survival and is associated with well differentiated tumours [98]. Mingzhu et al. found ER- and PR-positive tumours to be associated with better clinical outcome: early age, early stage, endometrioid subtype, high grade, less lymph node involvement, and less recurrence [99]. Ferrandina et al. investigated the expression of ER and PR in endometrial cancer and association of ER and PR with clinicopathological parameters. They found that ER and PR positivity was higher in patients with early stage of disease $(p<0.05)$, in cases of endometrioid cancer $(p<0.05)$ and in tumours with better grades of differentiation $(p<0.05)$. Furthermore, they showed a statistically significant relationship between ER positivity and negative lymph node status $(p<0.05)$ [100]. Huvilla et al. demonstrated that PR negativity is an independent prognostic factor for relapse in patients with early stage of endometrioid endometrial carcinoma [48].

\section{$\mathrm{Ki}-67$}

$\mathrm{Ki}-67$ is a marker of cell proliferation. In the majority of endometrioid endometrial cancers, the Ki-67 proliferation index is low and has a good prognosis. In con- 
Tab. V. E-cadherin expression in type I and II endometrial carcinoma

\begin{tabular}{|c|c|c|c|c|c|}
\hline \multirow{2}{*}{ Authors [ref.] } & \multicolumn{2}{|c|}{ Cases } & \multicolumn{2}{|c|}{ Negative E-cadherin expression, $n$ (\%) } & \multirow{2}{*}{$p$} \\
\hline & EEC & NEEC & EEC & EEC & \\
\hline Stefansson et al. [114] & 255 & 29 & $135(53)$ & $24(83)$ & 0.002 \\
\hline Moreno-Bueno et al. [115] & 95 & 33 & $41(50)$ & $27(87.1)$ & 0.001 \\
\hline Holcomb et al. [116] & 63 & 13 & $3(5)$ & $8(62)$ & $<0.001$ \\
\hline
\end{tabular}

EEC - endometrioid endometrial carcinoma, NEEC - non-endometrioid endometrial carcinoma

trast, most serous and clear cell tumours have a high proliferation index, which is associated with increased tumour aggressiveness [101]. Ferrandina et al. demonstrate a statistically significant relationship between Ki-67 positivity and tumour type-endometrioid endometrial carcinomas, advanced clinical stage of the disease, poor grade of differentiation, and deeper myometrial invasion $(p<0.05)$. They also report an inverse relationship between ER and Ki-67 $(p<0.009)$ and between PR and Ki-67 ( $p<0.008)$ [100]. Tumours with positive expression of Ki-67 and negative expression of ER and PR were associated with higher grade and poorer prognosis [48]. However, there are reports of a statistically significant relationship between increased expression of Ki-67 and advanced tumour stage, as well as relapse of the disease $[102,103]$.

\section{Cox-2}

Cyclooxygenase is an enzyme responsible for prostaglandin synthesis. Cyclooxygenase-2 (Cox-2) overexpression is correlated with neoangiogenesis, metastatic ability and poor prognosis, and the protein may play a critical role in carcinogenesis [104]. Cox-2 overexpression has been found in many tumours, including lung, skin, gastrointestinal tract, ovary, and cervical cancers $[105,106]$. Ferrandina et al. observed no clear correlation between Cox-2 positivity and any clinicopathological features [100]. However, Knapp et al. reported higher Cox-2 expression in endometrial carcinoma compared to samples from a healthy endometrium. They suggest that Cox-2 plays a role in carcinogenesis. Similarly, Keser et al. suggest that Cox-2 might be a new therapeutic target, but further studies are needed [107, 108].

\section{Adhesive molecules}

E-cadherin and $\beta$-catenin are two basic adhesion molecules relevant to endometrial cancer [109]. High expression of $\beta$-catenin is characteristic of endometrioid endometrial carcinoma (31-47\%) in contrast to nonendometrioid endometrial carcinoma (0-3\%) [110].

Mutations in the CTNNB1 gene, leading to high expression of $\beta$-catenin, are associated with low potential for metastasis. Loss of protein is an independent predictor of poor prognosis in patients with endometrial cancer [111, 112]. Low expression of E-cadherin and $\beta$-catenin correlates with poor prognosis.

Nei et al. reported greater $\beta$-catenin nuclear expression in endometrial hyperplasia than in endometrial carcinoma [113], which suggests that $\beta$-catenin is involved in the early stages of endometrial carcinogenesis. Saegusa et al. noted a significant relationship between $\beta$-catenin expression and low histological grade $(p=0.048)$, and that $\beta$-catenin expression was stronger in patients without lymph node metastases than in patients with them $(p=0.027)$ [111]. Low E-cadherin expression is characteristic of serous and clear cell endometrial carcinomas (Table V) [114-116].

Stefansson et al. reported low E-cadherin expression to be associated with high FIGO grade $(p=0.04)$, deep myometrial invasion $(p=0.02)$, high FIGO stage $(p=0.01)$, and vascular invasion $(p=0.04)$ [114]. E-cadherin overexpression is a positive prognostic factor in the clinical course of endometrioid endometrial cancer [117]. High E-cadherin expression is associated with reduced mortality, disease progression, and rate of disease recurrence [118].

\section{Conclusions}

The identification of novel mutations and molecular profiles should enhance our ability to personalise adjuvant treatment with genome-guided targeted therapy. In conclusion, mutations of PTEN and $\beta$-catenin are predictive of good prognosis, while DNA aneuploidy, p53 abnormalities, and elevated serum CA125 levels are usually associated with poor prognosis.

\section{Disclosure}

Authors report no conflict of interest.

\section{References}

1. Gabryś MS. Epidemiologia i etiopatogeneza raka błony śluzowej trzonu macicy. In: Ginekologia onkologiczna. Markowska H (ed.). Tom 2. Urban \& Partner, Wrocław 2006; 683-685.

2. World Cancer Report. Steward BW, Kleihues P (eds.). Uterine cancer. IARC Press, Lyon 2003; 217-219.

3. GLOBOCAN 2008. Cancer Incidence and Mortality Worldwide. IARC, Lyon 2008; http://globocan.iarc.fr/ 
4. Meyer LA, Broaddus RR, Lu KH. Endometrial cancer and Lynch syndrome: clinical and pathologic considerations. Cancer Control 2009; 16: 14-22.

5. Tumours of the uterine corpus. In: Pathology and genetics of tumors of the breast and female genital organs. Tavassoli FA, Devilee P (eds.). IARC Press, Lyon 2003; 217-257.

6. Urbański K, Kornafel J (eds.). Ginekologia onkologiczna. In: Zalecenia postępowania diagnostyczno-terapeutycznego w nowotworach złośliwych. Via Media, Gdańsk 2007. Część I. Onkologia w praktyce klinicznej 2007; 3 (suppl C): pp. 235-240.

7. Biomarkers Definitions Working Group. Biomarkers and surrogate endpoints: Preferred definitions and conceptual framework. Clin Pharmaco Ther 2001; 69: 89-95.

8. Ginath S, Menczer J, Fintsi Y, et al. Tissue and serum CA125 expression in endometrial cancer. Int J Gynecol Cancer 2002; 12: 372-375.

9. Powell JL, Hill KA, Shiro BC, et al. Preoperative serum CA-125 levels in treating endometrial cancer. J Reprod Med 2005; 50: 585-590.

10. Chung HH, Kim JW, Park NH, et al. Use of preoperative serum CA125 levels for prediction of lymph node metastasis and prognosis in endometrial cancer. Acta Obstet Gynecol Scand 2006; 85: 1501-1505.

11. Duk JM, Aalders JG, Fleuren GJ, de Bruijn HW. CA 125: a useful marker in endometrial carcinoma. Am J Obstet Gynecol 1986; 155: 1097-1102.

12. Niloff JM, Klug TL, Schaetzl E, et al. Evaluation of serum CA125 in carcinomas of the fallopian tube, endometrium and endocervix. Am J Obstet Gynecol 1984; 148: 1057-1058.

13. Sood AK, Buller RE, Burger RA, et al. Value of preoperative CA 125 leve in the management of uterine cancer and prediction of clinical outcome. Obstet Gynecol 1997; 90: 441-447.

14. Santala M, Talvensaari-Mattila A. Peritoneal cytology and preoperative serum Ca-125 level are important prognostic indicators of overall survival in advanced endometrial cancer. Anticancer Res 2003; 23: 3097 3103.

15. Saarelainen SK, Peltonen N, Lehtimaki T, et al. Predictive value of serum human epididymis protein 4 and cancer antigen 125 concentrations in endometrial carcinoma. Am J Obstet Gynecol 2013; 209: 142.e1-6

16. Scambia G, Gadducci A, Panici PB, et al. Combined use of CA 125 and CA 15-3 in patients with endometrial cancer. Gynecol Oncol 1994; 54 292-297.

17. Moore RG, Brown AK, Miller MC, et al. Utility of novel serum tumor biomarker HE4 in patients with endometrial adenocarcinoma of the uterus. Gynecol Oncol 2008; 110: 196-201.

18. Bignotti E, Ragnoli M, Zanotti L, et al. Diagnostic and prognostic impact of serum HE4 detection in endometrial carcinoma patients. Br J Cancer 2011; 104: 1418-1425.

19. Antonsen SL, Høgdall E, Christensen IJ, et al. HE4 and CA-125 levels in the preoperative assessment of endometrial cancer patients: a prospective multicenter study (ENDOMET). Acta Obstet Gynecol Scand 2013; 92: 1313-1322.

20. Angioli R, Plotti F, Capriglione S, et al. The role of novel biomarker HE4 in endometrial cancer: a case control prospective study. Tumour Bio 2013; 34: 571-576.

21. Mutz-Dehbalaie I, Egle D, Fessler S, et al. HE4 is an independent prognostic marker in endometrial cancer patients. Gynecol Oncol 2012; 126 186-191.

22. Żyła MM, Kostrzewa M, Litwińska E, et al. The role of angiogenic factors in endometrial cancer. Prz Menopauz 2014; 18: 122-126.

23. Sivridis E. Angiogenesis and endometrial cancer. Anticancer Res 2001 21: 4383-4388.

24. Dobrzycka B, Terlikowski SJ, Kwiatkowski M, et al. Prognostic significance of VEGF and its receptors in endometrioid endometrial cancer. Gin Pol 2010; 81: 422-425.

25. Kamat AA, Merritt WM, Coffey D, et al. Clinical and biological significance of vascular endothelial growth factor in endometrial cancer. Clin Cancer Res 2007; 13: 7487-7495

26. Hirai $M$, Nakagawara A, Oosaki T, et al. Expression of vascular en dothelial growth factors (VEGF-A/VEGF-1 and VEGF-C/VEGF-2) in postmenopausal uterine endometrial carcinoma. Gynecol Oncol 2001; 80: 181-188.

27. Giatromanolaki A, Sivridis E, Brekken R, et al. The angiogenic "vascular endothelial growth factor/flk-1(KDR) receptor" pathway in patients with endometrial carcinoma: prognostic and therapeutic implications. Cancer 2001: 92: 2569-2577.
28. Fine BA, Valente PT, Feinstein GI, Dey T. VEGF, flt-1 and KDR.flk-1 as prognostic indicators in endometrial carcinoma. Gynecol Oncol 2000; 76: 33-39.

29. Maae E, Olsen DA, Steffensen KD, et al. Prognostic impact of placenta growth factor and vascular endothelial growth factor $A$ in patients with breast cancer. Breast Cancer Res 2012; 133: 257-265.

30. Sung CY, Son MW, Ahn TS, et al. Expression of placenta growth factor in colorectal carcinomas. J Korean Soc Coloproctol 2012; 28: 315-320.

31. Coenegrachts L, Schrauwen S, Van Bree R, et al. Increased expression of placental growth factor in high grade endometrial carcinoma. Oncology Rep 2013; 29: 413-418.

32. Wik E, Trovik J, Iversen OE, et al. Deoxyribonucleic acid ploidy in endometrial carcinoma: a reproducible and valid prognostic marker in a routine diagnostic setting. Am J Obstet Gynecol 2009; 201: 1-7.

33. Pradhan M, Abeler VM, Danielsen HE, et al. Prognostic importance of DNA ploidy and DNA index in stage I and II endometrioid adenocarcinoma of the endometrium. Ann Oncol 2011; 23: 1178-1184.

34. Susini T, Amunni G, Molino C, et al. Ten-years results of a prospective study on the prognostic role of ploidy in endometrial carcinoma. Cancer 2007; 109: 882-890.

35. Mutter GL. PTEN, a protean tumor suppressor. Am J Pathol 2001; 158: 1895-1898.

36. Prat J, Gallardo A, Cuatrecasas M, et al. Endometrial carcinoma: pathology and genetics. Pathology 2007; 39: 72-87.

37. Salvesen HB, Stefansson I, Kretzschmar El, et al. Significance of PTEN alterations in endometrial carcinoma: a population-based study of mutations, promoter methylation and PTEN protein expression. Int J Oncol 2004; 25: 1615-1623.

38. Maxwell GL, Risinger Jl, Gumbs C, et al. Mutations of the PTEN tumor suppressor gene in endometrial hyperplasia. Cancer Res 1998; 58: 2500-2503.

39. Shen WH, Balajee AS, Wang J, et al. Essential role for nuclear PTEN in maintenance chromosomal integrity. Cell 2007; 128: 157-170.

40. McConechy MK, Ding J, Senz J, et al. Ovarian and endometrial endometrioid carcinomas have distinct CTNNB1 and PTEN mutation profiles. Mod Pathol 2014; 27: 128-134

41. Mackay HJ, Gallinger S, Tsao MS, et al. Prognostic value of microsatellite instability (MSI) and PTEN expression in women with endometrial cancer: results from studies of the NCIC Clinical Trials Group (NCIC CTG). Eur J Cancer 2010; 46: 1365-1373.

42. Kaku T, Kamura T, Hirakawa T, et al. Endometrial carcinoma associated with hyperplasia-immunohistochemical study of angiogenesis and p53expression. Gynecol Oncol 1999; 72: 51-55.

43. Athanassiadou $P$, Athanassiades $P, G r a p s a ~ D$, et al. The prognostic value of PTEN, p53, and beta-catenin in endometrial carcinoma: a prospective immunocytochemical study. Int J Gynecol Cancer 2007; 17: 697-704.

44. Lee EJ, Kim TJ, Kim DS, et al. p53 alteration independently predicts poor outcomes in patient with endometrial cancer: a clinicopathological study of 131 cases and literature review. Gynecol Oncol 2010; 116: 533-538.

45. Urabe R, Hachisuga T, Kurita T, et al. Prognostic significance of overexpression of $\mathrm{p} 53$ in uterine endometrioid adenocarcinomas with an analysis of nuclear grade. J Obstet Gynaecol Res 2014; 40: 812-819.

46. Lia L, Liu Y, Yi X, et al. Endometrial glandular dysplasia with frequent p53 gene mutation: a genetic evidence supporting its precancer nature for endometrial serous carcinoma. Clin Cancer Res 2008; 14: 2263-2269.

47. Lax SF, Kendall B, Tashiro H, et al. The frequency of p53, K-ras mutations and microsatellite instability differs in uterine endometrioid and serous carcinoma: evidence of distinct molecular genetic pathways. Cancer 2000; 88: 814-824.

48. Huvila J, Talve L, Carpen O, et al. Progesterone receptor negativity is an independent risk factor for relapse in patients with early stage endometrioid endometrial adenocarcinoma. Gynecol Oncol 2013; 130: 463-469.

49. Dupont, J, Wang X, Marshall DS, et al. Wilms Tumor gene (WT1) and p53 expression in endometrial carcinomas: a study of 130 cases using a tissue microarray. Gynecol Oncol 2004; 94: 449-455.

50. Zając A, Stachowiak G, Stetkiewicz T, et al. TP53 gene and p53 protein vs. endometrial carcinoma. Prz Menopauz 2013; 3: 228-230.

51. Saffari B, Bernstein L, Hong DC, et al. Association of p53 mutations and a codon 72 single nucleotide polymorphism with lower overall survival and responsiveness to adjuvant radiotherapy in endometrioid endometrial carcinomas. Int J Gynecol Cancer 2005; 15: 952-963. 
52. Salvesen HB, Das S, Akslen LA. Loss of nuclear p16 protein expression is not associated with promoter methylation but defines a subgroup of aggressive endometrial carcinomas with poor prognosis. Clin Cancer Res 2000; 6: 153-159.

53. Netzer IM, Kerner H, Litwin L, et al. Diagnostic implications of p16 expression in serous papillary endometrial cancer. Int J Gynecol Cancer 2011; 21: 1441-1445.

54. Alkushi A, Kobel M, Kalloger SE, et al. High-grade endometrial carcinoma: serous and grade 3 endometrioid carcinomas have different immunophenotypes and outcomes. Int J Gynecol Cancer 2010; 29: 343-350.

55. Abu Backer FM, Nik Mustapha NR, Othman NH. Clinicopathological comparison of adenocarcinoma of cervix and endometrium using cell cycle markers: P16ink4a, P21waf1, and p27Kip1 on 132 cancers. Infect Dis Obstet Gynecol 2011; 2011: 1-6.

56. Yarden Y, Sliwkowski MX. Untangling the ErbB signaling network. Nat Rev Mol Cell Biol 2001; 2: 127-137.

57. Williams Jr JA, Wang ZR, Parrish RS, et al. Fluorescence in situ hybridization analysis of HER2/neu, c-myc, and p53 in endometrial cancer. Exp Mol Pathol 1999; 67: 135-143.

58. Morrison C, Zanagnolo V, Ramirez N, et al. HER-2 is an independent prog nostic factor in endometrial cancer: association with outcome in a large cohort of surgically staged patients. J Clin Oncol 2006; 24: 2376-2385.

59. Santin AD, Bellone S, Van Stedum S, et al. Amplification of c-erbB2 oncogene: a major prognostic indicator in uterine serous papillary carcinoma. Cancer 2005; 104: 1391-1397.

60. Grushko TA, Filiaci VL, Mundt AJ, et al. An exploratory analysis of HER-2 amplification and overexpression in advanced endometrial carcinoma: a Gynecologic Oncology Group study. Gynecol Oncol 2008; 108: 3-9.

61. Slomovitz BM, Broaddus RR, Burke TW, et al. Her2/neu overexpression and amplification in uterine papillary serous carcinoma. J Clin Oncol 2004; 22: 3126-3132

62. Fleming GF, Sill MW, Darcy KM, et al. Phase II trial of trastuzumab in women with advanced or recurrent, HER2-positive endometrial carcinoma: a Gynecologic Oncology Group study. Gynecol Oncol 2010; 116: 15-20.

63. Xu M, Schwartz P, Rutherford T, et al. HER-2/neu receptor gene status in endometrial carcinomas: a tissue microarray study. Histopathology 2010; 56: 269-273.

64. Togami S, Sasajima Y, Oi T, et al. Clinicopathological and prognostic impact of human epidermal growth factor receptor type 2 (HER2) and hormone receptor expression in uterine papillary serous carcinoma. Cancer Sci 2012; 103: 926-932.

65. Singh P, Smith CL, Cheetham G, et al. Serous carcinoma of the uterus determination of HER-2/neu status using immunohistochemistry, chromogenic in situ hybridization, and quantitative polymerase chain reac tion techniques: its significance and clinical correlation. Int J Gyneco Cancer 2008; 18: 1344-1351.

66. Santin AD, Bellone S, Gokden M, et al. Overexpression of HER-2/neu in uterine serous papillary cancer. Clin Cancer Res 2002; 8: 1271-1279.

67. Togami S, Sasajima Y, Oi T, et al. Clinicopathological and prognostic impact of human epidermal growth factor receptor type 2 (HER2) and hormone receptor expression in uterine papillary serous carcinoma. Cancer Sci 2012; 103: 926-932

68. Santin AD, Bellone S, Roman JJ, et al. Trastuzumab treatment in patients with advanced or recurrent endometrial carcinoma overexpressing HER2/neu. Int J Gynaecol Obstet 2008; 102: 128-131.

69. Jewell E, Secord AA, Brotherton T, et al. Use of trastuzumab in the treatment of metastatic endometrial cancer. Int J Gynecol Cancer 2006; 16: 1370-1373.

70. Engelman JA. Targeting PI3K signaling in cancer: opportunities, challenges and limitations. Nat Rev Cancer 2009; 9: 550-562.

71. Sansal I, Sellers WR. The biology and clinical relevance of The PTENT tumor suppressor pathway. J Clin Oncol 2004; 22: 2954-2963.

72. Cheung LW, Hannessy BT, Li J, et al. High frequency of PI3KR1and PI3KR2 mutations in endometrial cancer elucidates a novel mechanism for regulation of PTEN protein stability. Cancer Discov 2011; 1: 170-185.

73. Catasus L, Gallardo A, Cuatrecases M, et al. Concomitant PI3K-AKT and p53 alterations in endometrial carcinomas are associated with poor prognosis. Mod Pathol 2009; 22: 522-529.

74. Oda K, Stokoe D, Taketani Y, McCormick F. High frequency of coexistent mutations of PIK3CA and PTEN genes in endometrial carcinoma. Cancer Res 2005; 65: 10669-10673.
75. No JH, Jeon YT, Park IA. Expression of mTOR protein and its clinical significance in endometrial cancer. Med Sci Monit 2009; 15: 301-305.

76. Soufla G, Sifakis S, Spandidos DA. FGF2 transcript levels are positively correlated with EFG and IGF-1 in the malignant endometrium. Cancer Lett 2008; 259: 146-155

77. Byron SA, Gartside MG, Wellens CL, et al. Inhibition of activated fibroblast growth factor 2 in endometrial cancer cells induces cells death despite PTEN abrogation. Cancer Res 2008; 68: 6902-6907.

78. Byron SA, Pollock PM. FGFR2 as a molecular target in endometrial cancer. Future Oncol 2009; 5: 27-32.

79. Llobet D, Pallares J, Yeramian A, et al. Molecular pathology of endometrial carcinoma: practical aspects from the diagnostic and therapeutic viewpoint. J Clin Pathol 2009; 62: 777-785.

80. Cohn DE, Mutch DG, Herzog TJ, et al. Genotypic and phenotypic progres sion in endometrial tumoriogenesis: determining when defects in DNA mismatch repair and KRAS2 occur. Genes Chromosomes Cancer 2001; 32: 295-301.

81. Dobrzycka B, Terlikowski SJ, Mazurek A, et al. Mutations of the K-ras oncogene in endometrial hyperplasia and carcinoma. Folia Histochem Cytobiol 2009; 47: 65-68

82. Hachisuga T, Miyakawa T, Tsujioka H, et al. K-ras mutation in tamoxifenrelated endometrial polyps. Cancer 2003; 98: 1890-1897.

83. Wallen M, Tomas E, Visakorpi T, et al. Endometrial K-ras mutations in postmenopausal breast cancer patients treated with adjuvant tamoxifen or toremifene. Cancer Chemother Pharmacol 2005; 55: 343-346.

84. Fujimoto I, Shimizu Y, Hirai Y, et al. Studies on ras oncogene activation in endometrial carcinoma. Gynecol Oncol 1993; 48: 196-202.

85. Mizuuchi H, Nasim S, Kudo R, et al. Clinical implications of K-ras mutations in malignant epithelial tumors of the endometrium. Cancer Res 1992; 52: 2777-2781.

86. Popat S, Hubner R, Houlston RS. Systematic review of microsatellite instability and colorectal cancer prognosis. J Clin Oncol 2005; 23: 609-618.

87. Buecher B, Cacheux W, Rouleau E, et al. Role of microsatellite instability in the management of colorectal cancers. Dig Liver Dis 2013; 45: 441-449.

88. Salvesen HB, Akslen LA. Molecular pathogenesis and prognostic factors in endometrial carcinoma. APMIS 2002; 110: 673-689.

89. Kinzler KW, Vogelstein B. Cancer-susceptibility genes. Gatekeepers and caretakers. Nature 1997; 386: 761-763.

90. Dunlop MG, Farrington SM, Carothers AD, et al. Cancer risk associated with germline DNA mismatch repair gene mutations. Hum Mol Genet 1997; 6: 105-110.

91. Sobczuk A, Smolarz B, Romanowicz-Makowska H, et al. Microsatellite instability in women with endometrial cancer from the Lodz region of Poland. Prz Menopauz 2008; 1: 42-45

92. An HJ, Kim KI, Kim JY, et al. Microsatellite instability in endometrioid type endometrial adenocarcinoma is associated with poor prognostic indicators. Am J Surg Pathol 2007; 31: 846-853.

93. Black D, Soslow RA, Levine DA, et al. Clinicopathologic significance of defective DNA mismatch repair in endometrial carcinoma. J Clin Oncol 2006; 24: 1745-1753.

94. Maxwell GL, Risinger JI, Alwarez AA, et al. Favorable survival associated with microsatellite instability in endometrioid endometrial cancers. Obstet Gynecol 2001; 97: 417-422.

95. Arabi H, Guan H, Kumar S, et al. Impact of microsatellite instability (MSI) on survival in high grade endometrial carcinoma. Gynecol Oncol 2009; 113: 153-158.

96. Basil JB, Goodfellow PJ, Rader JS, et al. Clinical significance of microsatellite instability in endometrial carcinoma. Cancer 2000; 89: 1758-1764.

97. Steinbakk A, MalpicaA, Slewa A, et al. High frequency microsatellite in stability has a prognostic value in endometrial endometrioid adenocarcinoma, but only in FIGO stage 1 cases. Anal Cell Pathol 2010; 33: 245-255.

98. Markova I, Duskova M, LubuskyM, et al. Selected immunohistochemical prognostic factors in endometrial cancer. Int J Gynecol Cancer 2010; 20: 576-582.

99. Mingzhu L, Zhao L, Shen D, et al. Clinical implications and prognostic value of single and combined biomarkers in endometrial carcinoma. Chin Med J 2014; 127: 1459-1463.

100. Ferrandina $G^{1}$, Ranelletti FO, Gallotta V, et al. Expression of cyclooxygenase-2 (COX-2), receptors for estrogen (ER) and progesterone (PR), p53, ki67 and neu protein in endometrial cancer. Gynecol Oncol 2005; 98: 383-389. 
101. Horrée N, van Diest PJ, Sie-Go DM, Heintz AP. The invasive front in endometrial carcinoma: higher proliferation and associated derailment of cell cycle regulators. Hum Pathol 2007; 38: 1232-1238.

102. Gottwald L, Kubiak R, Sęk P, et al. The value of Ki-67 antigen expression in tissue microarray method in prediction prognosis of patients with endometrioid endometrial carcinoma. Ginekol Pol 2013; 84: 444-449.

103. Stefansson I, Salvesen H, Immervoll H, et al. Prognostic impact of histological grade and vascular invasion compared with tumor cell proliferation in endometrial carcinoma of endometrioid type. Histopathology 2004; 44: 472-479.

104. Rozic JG, Chakraborty C, Lala PK. Cyclooxygenase inhibitors retard murine mammary tumor progression by reducing tumor cell migration, invasiveness and angiogenesis. Int J Cancer 2001; 93: 497-506.

105. Fosslien E. Molecular pathology of cyclooxygenase-2 in neoplasia. Ann Clin Lab Sci 2000; 30: 3-21.

106. Sinicrope FA, Gillis S. Role of cyclooxygenase-2 in colorectal. Cancer Metastasis Rev 2004; 23: 63-75.

107. Knapp P, Chabowski A, Błachnio-Zabielska A, et al. Expression of estrogen receptors $(\alpha, \beta)$, cyclooxygenase- 2 and aromatase in norma endometrium and endometrioid cancer of uterus. Adv Med Sci 2013; 58: 96-103.

108. Keser SH, Gül AE, Barişik NO, et al. The relationship of COX-2 expression with estrogen receptor, progesterone receptor and prognostic parameters in endometrial carcinomas. J Obstet Gynaecol Res 2010; 36: 560-566.

109. Wojciechowski M, Krawczyk T, Śmigielski J, et al. The role of adhesive molecules in endometrial cancer: part I. Prz Menopauz 2010; 5: 291-295.

110. Moreno-Bueno G, Hardisson D, Sanchez C, et al. Abnormalities of the APC/B-catenin pathway in endometrial cancer. Oncogene 2002; 21: 7981-7990.

111. Saegusa M, Hashimura M, Yoshida T, et al. Beta-catenin mutations and aberrant nuclear expression during endometrial tumorigenesis. $\mathrm{Br}$ J Cancer 2001; 84: 209-217.

112. Fukuchi T, Sakamoto $M$, Tsuda $H$, et al. Beta-catenin mutation in carcinoma of the uterine endometrium. Cancer Res 1998; 58: 3526-3528.

113. Nei H, Saito T, Yamasaki H, et al. Nuclear localization of B-catenin in normal and carcinogenic endometrium. Mol Carcinog 1999; 25: 207-218.

114. Stefansson IM, Salvesen HB, Akslen LA. Prognostic impact of alterations in $\mathrm{p}$-cadherin expression and related cell adhesion markers in endometrial cancer. J Clin Oncol 2004; 22: 1242-1252.

115. Moreno-Bueno G, Hardisson D, Sarrio D, et al. Abnormalities of E- and $\mathrm{P}$-cadherin and catenin ( $\beta$-, $\gamma$-catenin, and p120ctn) expression in endometrial cancer and endometrial atypical hyperplasia. J Pathol 2003; 199: 471-478.

116. Holcomb K, Delatorre R, Pedemonte B, et al. E-cadherin expression in endometrioid, papillary serous, and clear cell carcinoma of the endometrium. Obstet Gynecol 2002; 100: 1290-1295.

117. González-Rodilla I, Aller L, Llorca J, et al. The E-cadherin expression vs. tumor cell proliferation paradox in endometrial cancer. Anticancer Res 2013; 33: 5091-5095.

118. Mell LK, Meyer JJ, Tretiacova M, et al. Prognostic significance of E-cadherin protein expression in pathological stage I-III endometrial cancer. Clin Cancer Res 2004; 10: 5546-5553. 